\title{
Comparison of transvaginal excision with laparotomy in the treatment of cesarean scar pregnancy
}

Hui $\mathrm{Fei}^{1}$, shanrong shu ${ }^{2}$, Tian $\mathrm{Li}^{1}$, and Hongling Guo ${ }^{1}$

${ }^{1}$ The Seventh Affiliated Hospital of Sun Yat-sen University

${ }^{2}$ The First Afliated Hospital of JiNan University

September 11, 2020

\section{Abstract}

The transvaginal excision of lesion seems to a feasible and safe approach to treat cesarean scar pregnancy.

\section{Hosted file}

manuscript-revise - 8.26. docx available at https://authorea.com/users/356521/articles/480585comparison-of-transvaginal-excision-with-laparotomy-in-the-treatment-of-cesarean-scarpregnancy 